\title{
12. RADIOMETRIC AGE AND PALEOMAGNETIC RESULTS FROM SEYCHELLES DIKES ${ }^{1}$
}

\author{
R. B. Hargraves ${ }^{2}$ and R. A. Duncan ${ }^{3}$
}

\begin{abstract}
Potassium-argon and ${ }^{40} \mathrm{Ar} /{ }^{39} \mathrm{Ar}$ measurements on samples from six mafic dikes that intrude Precambrian granites in the Seychelles Islands (Indian Ocean) indicate that they crystallized about $620 \mathrm{Ma}$ and were uralitized penecontemporaneously or soon thereafter. Stable paleomagnetic directions from two of the six dikes sampled determine a pole position that, in a Gondwana reconstruction, agrees well with the one reported from the late Precambrian Nama Group in southwestern Africa. The paleomagnetic data thus support previous plate reconstructions of the Seychelles Bank between northern Madagascar and western India, adjacent to the Somali coast of eastern Africa.
\end{abstract}

\section{INTRODUCTION}

The Seychelles Islands are unusual among oceanic islands in that they are composed primarily of granite (Baker, 1963). Radiometric ages on rocks from these islands (Baker and Miller, 1963) revealed that the granites crystallized about 650 m.y. ago. A suite of basic dikes intrude the granite. These range in petrology from slightly uralitized augitic dolerite to epidiorite, and they yield late Precambrian to early Paleozoic K-Ar ages. From their varying alteration and structural relations with respect to the granite, these dikes could well have been intruded while the granite, at least in places, was still hot. Another suite of dikes present on the islands are composed of unaltered alkali olivine dolerite; a sample from Praslin Island yielded Eocene ages, as did syenites from a ring complex on Silhouette Island (Baker and Miller, 1963). An early paleomagnetic study of the Seychelles dikes was completely unsuccessful (Matthews and Reilly, 1964).

In 1981, oriented samples from six different dikes on the island of Mahé (Fig. 1) were collected for further paleomagnetic and radiometric study. An average of six separate cores was drilled in the field at each site and oriented with a sun compass. Sites 3 and 4, from Bel Ombre, represent a dike $8 \mathrm{~m}$ thick (Site 3 ) cut at one point by thin $(<30 \mathrm{~cm})$ en echelon dikelets (Site 4). It was hoped that Site 4, in particular, might be from the Tertiary group of intrusives, thereby enabling a test of the hypothesis of Emerick and Duncan (1982) that the Tertiary igneous activity on these islands was stimulated by the passage of the Seychelles Bank over the Comores hotspot.

\section{RESULTS}

As seen in polished thin sections, hornblende is the dominant ferromagnesian phase in all dikes, occurring as a replacement for augite (uralite) in some dikes (Site 3). In other dikes, however, it appears as if it were a primary microphenocryst phase. Alteration to chlorite is common in some dikes. Plagioclase is generally fresh and usually zoned. The Fe-Ti oxides, recognizable by relict high-temperature exsolution textures, are extensively altered to whitish leucoxenic material. Pyrite, where present, is always perfectly fresh. Petrographically, these dikes

\footnotetext{
${ }^{1}$ Duncan, R. A., Backman, J., Peterson, L. C., et al., 1990. Proc. ODP, Sci. Results, 115: College Station, TX (Ocean Drilling Program).

2 Department of Geological and Geophysical Sciences, Princeton University, Princeton, NJ 08544, U.S.A.

${ }^{3}$ College of Oceanography, Oregon State University, Corvallis, OR 97331,
}

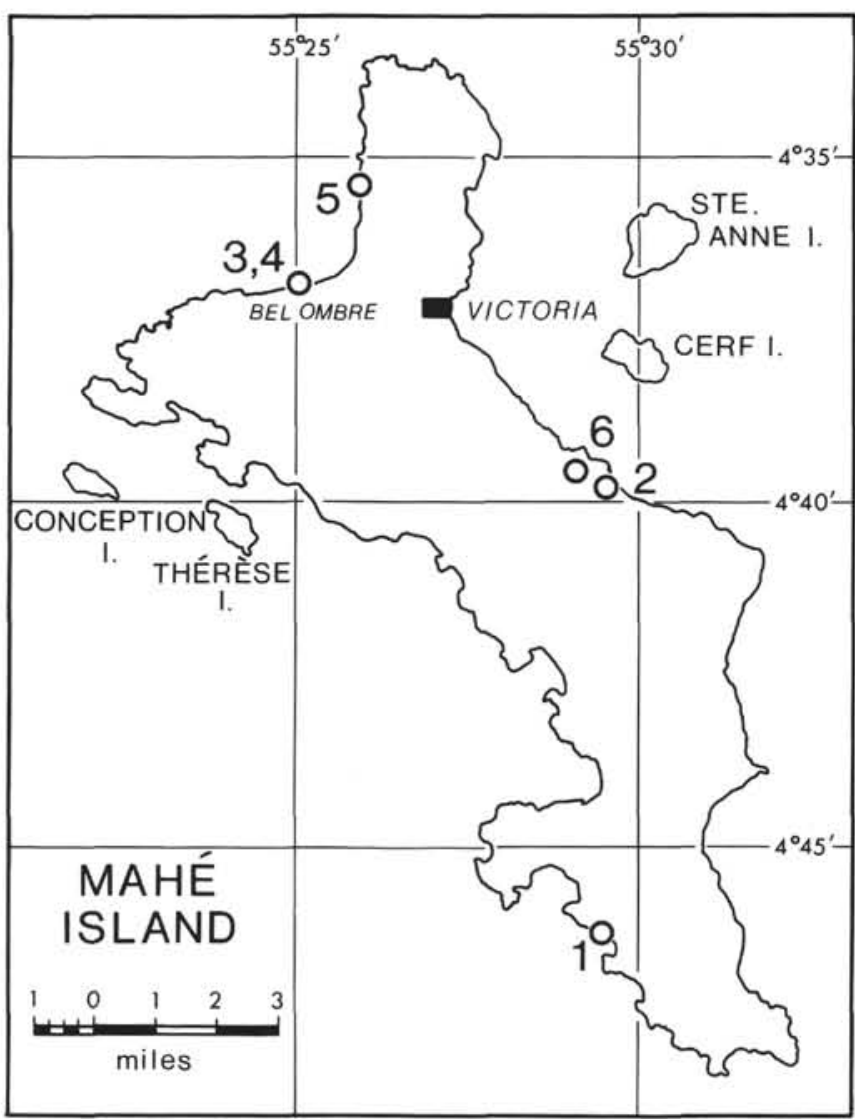

Figure 1. Map of Mahé Island, including the sites sampled for this study.

are exactly as described by Baker (1963), who also provided representative chemical analyses.

The K-Ar age determinations performed at Oregon State University on samples from the six sites (Table 1) range from 450 to 650 m.y.; no Tertiary dikes were collected. [Macintyre et al. (1985) have reported $\mathrm{Rb}-\mathrm{Sr}$ and $\mathrm{K}-\mathrm{Ar}$ age determinations that place the peak of the Tertiary magmatic activity (mafic dykes and alkaline intrusions) at $63 \mathrm{Ma}$.] All samples exhibit variable amounts of secondary alteration in the form of replacement minerals uralite and chlorite; hence, all measured ages could be considered minimum ages. The ${ }^{40} \mathrm{Ar} /{ }^{39} \mathrm{Ar}$ step heating analysis was performed at Princeton University on whole rock chip sam- 
Table 1. K-Ar age determinations on Seychelles dikes.

\begin{tabular}{cccrc}
\hline $\begin{array}{c}\text { Site } \\
\text { number }\end{array}$ & $\begin{array}{c}\mathrm{K} \\
(\%)\end{array}$ & $\begin{array}{c}\text { Rad. }{ }^{40} \mathrm{Ar} \\
\left(\times 10^{-4} \mathrm{~cm}^{3} / \mathrm{g}\right)\end{array}$ & $\begin{array}{c}\text { Rad. }{ }^{40} \mathrm{Ar} \\
(\%)\end{array}$ & $\begin{array}{c}{ }^{\mathrm{a}} \mathrm{Age} \pm 1 \sigma \\
\left(\times 10^{6} \mathrm{yr}\right)\end{array}$ \\
\hline 1 & 0.840 & 0.16579 & 97.2 & $447.7 \pm 4.9$ \\
2 & 2.300 & 0.51222 & 99.3 & $497.8 \pm 5.4$ \\
3 & 0.810 & 0.22601 & 97.9 & $604.6 \pm 6.5$ \\
4 & 0.373 & 0.09667 & 100.0 & $567.7 \pm 6.2$ \\
& 0.727 & 0.22019 & 99.4 & $648.0 \pm 7.2$ \\
5 & 0.779 & 0.20571 & 98.2 & $576.9 \pm 6.6$ \\
6 & 1.826 & 0.47753 & 99.5 & $572.1 \pm 6.3$ \\
\hline
\end{tabular}

Note: Rad. = radiogenic.

${ }^{a}$ Ages were calculated from the following decay and abundance constants: $\lambda_{e}=0.581 \times 10^{-10} \mathrm{yr}^{-1} ; \lambda_{\beta}=4.962 \times 10^{-10}$ $\mathrm{yr}^{-1} \cdot{ }^{40} \mathrm{~K} / \mathrm{K}=1.167 \times 10^{-4} \mathrm{~mol} / \mathrm{mol}$.

ples from Sites 4 and 5, which gave the only consistent paleomagnetic data (see the discussion that follows). The results are presented in Figure 2 and Tables 2 and 3. The release spectra are irregular and clearly disturbed, with low ages at the low-temperature steps, and high ages for the highest-temperature steps. Most of the gas fractions released from both samples, however, give ages between 600 and $650 \mathrm{Ma}$.
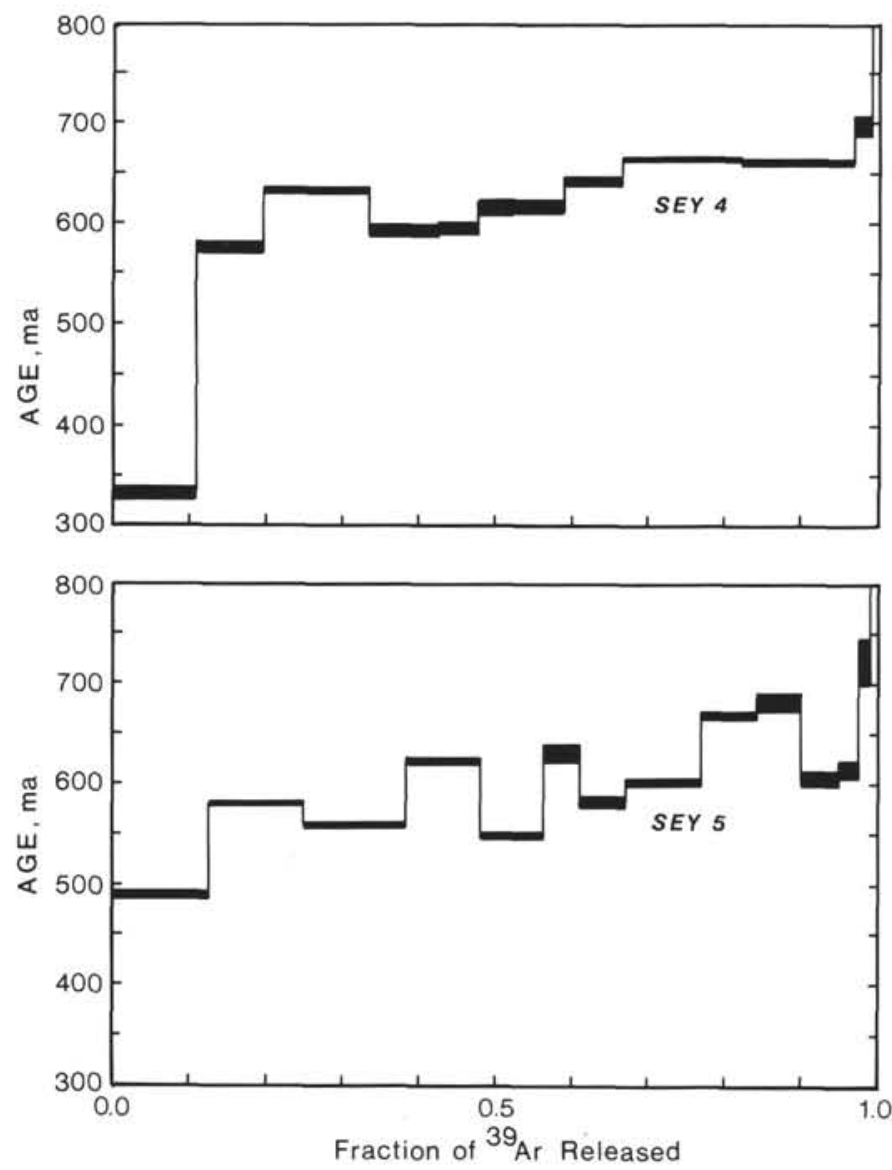

Figure $2 .{ }^{40} \mathrm{Ar} /{ }^{39} \mathrm{Ar}$ age spectra for whole-rock samples from Sites 4 and 5.

The data were analyzed by various methods (plateau, isochron, correlation diagram) and, depending upon which data are excluded, various results, with varying errors (usually large), were obtained (see Table 2). We concluded that the best estimate of the age of basaltic dike crystallization, taking all data into account, is $620 \pm 20 \mathrm{Ma}$, or latest Precambrian time. The magnetization (see discussion that follows) was acquired at this time. From the petrographic examination, we concluded that uralite formed partially as a replacement for phenocrystic pyroxene and partially as a primary groundmass amphibole as the dikes cooled in contact with hydrothermal fluids. The range in conventional $\mathrm{K}$ - $\mathrm{Ar}$ ages (450-650 Ma) appears to reflect variable alteration of the dike rocks by very low-temperature groundwater, subsequent to crystallization. These fluids probably added potassium (picked up from the granites?) to the basalts over a long period, ending more recently than $450 \mathrm{Ma}$.

Detailed alternating-field (AF) demagnetization of specimens from all samples from all sites was performed, but the results were widely scattered, with the exception of Sites 4 and 5. Site 1 appears to have been struck by lightning. Sites 2 and 6 were from thin $(<30 \mathrm{~cm})$ dikelets following near-horizontal joints in the granite in two quarries. Samples from these sites were extremely weakly magnetized, with pyrite the only opaque phase. Site 3 represents the main 8 -m dike (strike $70^{\circ}$ ) on shore opposite Bel Ombre Church; the results from here were also widely scattered.

Samples from Site 4 , from the thin dikes (strike $315^{\circ}$ ) that cut the Site 3 dike, and from a 2 -m dike (strike uncertain) on shore below Northolme Hotel all gave consistent results. Above $10-15 \mathrm{mT}$ and up to $50-70 \mathrm{mT}$, the vector regressed linearly to the origin, decreasing in intensity to $<5 \%$ of the natural remanent magnetization (NRM) (Fig. 3). In higher fields, the directions scattered.

The individual sample vectors used in the averages (Table 4) were derived by least-squares fitting of a line (Kirschvink, 1980) to at least four consecutive demagnetization steps between 5 and $50 \mathrm{mT}$. The average mean angular deviation (Kirschvink, 1980) was $1^{\circ}$ and $3^{\circ}$ for Sites 4 and 5 , respectively.

Detailed thermal demagnetization to $680^{\circ} \mathrm{C}$ of one specimen from each site revealed that the common stable vector component was unblocked between $500^{\circ}$ and $590^{\circ}$ (Fig. 3). These data are consistent with magnetite as the carrier of the stable remanence. Because unaltered primary magnetite grains were not seen in the polished thin sections, we suspect that fine-grained magnetite was produced as a by-product of the uralitization/chloritization that these rocks have experienced. The $620 \pm 20 \mathrm{Ma}$ estimated from the radiometric results would apply to this alteration and, hence, is the age of the magnetization.

The pole position calculated from the mean vector is listed in Table 5. However, because only two paleomagnetic sampling sites are involved, the Seychelles pole must be regarded as provisional. Also given in Table 5 is the pole position after rotation of the Seychelles Bank first back to Madagascar and then back to Africa, in the order of seafloor-spreading events in the western Indian Ocean (Emerick, 1985). The rotation poles and angles used are also given in Table 5 . The restored pole $\left(60.2^{\circ} \mathrm{N}\right.$, $\left.65.4^{\circ} \mathrm{E}\right)$ agrees closely with the $\mathrm{N} 1$ pole $\left(61^{\circ} \mathrm{N}, 63^{\circ} \mathrm{E}\right)$ reported by Kroner et al. (1980) from the late Precambrian part of the Nama Group in Namibia (African Plate). This is consistent with the Seychelles having been adjacent to Somalia in a Gondwana configuration relative to the Kalahari craton at that time.

\section{ACKNOWLEDGMENTS}

R. B. Hargraves would like to thank P. F. Shilton, R. Parker, and J. Causton for their assistance and advice during the field work on Mahé, and T. C. Onstott, R. Henne, and D. Thompson for their instruction and help with the ${ }^{40} \mathrm{Ar} /{ }^{39} \mathrm{Ar}$ analyses at Princeton. This research was supported by NSF Grant EAR 8212736 (R.B.H.) and NSF Grant OCE 8219189 (R.A.D.). 
Table $2 .{ }^{40} \mathrm{Ar} /{ }^{39} \mathrm{Ar}$ analytical data from Seychelles Site 4 whole-rock samples.

\begin{tabular}{rccccccc}
\hline $\begin{array}{c}\mathrm{T} \\
\left({ }^{\circ} \mathrm{C}\right)\end{array}$ & ${ }^{\mathrm{a}_{1}}$ & ${ }^{\mathrm{a}_{2}}$ & $\begin{array}{c}\text { Atmos. } \\
(\%)\end{array}$ & $\begin{array}{c}{ }^{40} \mathrm{Ar} \\
\left(\times 10^{-6} \mathrm{~cm}^{3} \mathrm{STP}\right)\end{array}$ & $\begin{array}{c}{ }^{\mathrm{b}} \mathrm{Cum} \\
\mathrm{f}(39)\end{array}$ & ${ }^{37} \mathrm{Ar}_{\mathrm{Ca}}{ }^{39} \mathrm{Ar}_{\mathrm{K}}$ & $\begin{array}{c}{ }^{\mathrm{c}} \mathrm{Age} \\
(\mathrm{Ma})\end{array}$ \\
\hline 550.0 & -0.00050 & 0.02977 & 8.2 & 1.033 & 0.109 & 0.774 & $331.1 \pm 5.9$ \\
600.0 & -0.00046 & 0.06785 & 1.8 & 1.505 & 0.195 & 0.703 & $575.1 \pm 4.8$ \\
650.0 & -0.00035 & 0.53033 & 0.1 & 2.774 & 0.336 & 0.540 & $633.4 \pm 3.0$ \\
700.0 & -0.00052 & 0.17591 & 0.7 & 1.653 & 0.427 & 0.799 & $592.2 \pm 5.4$ \\
750.0 & -0.00110 & 0.61853 & 0.2 & 0.945 & 0.478 & 1.692 & $596.3 \pm 6.4$ \\
800.0 & -0.00145 & 0.5898 & 0.3 & 0.875 & 0.524 & 2.226 & $615.6 \pm 7.4$ \\
850.0 & -0.00172 & 0.63944 & 0.3 & 1.216 & 0.588 & 2.640 & $617.1 \pm 6.9$ \\
900.0 & -0.00228 & 0.62107 & 0.4 & 1.537 & 0.665 & 3.510 & $642.0 \pm 4.1$ \\
950.0 & -0.00457 & 0.57330 & 0.8 & 3.256 & 0.821 & 7.020 & $664.1 \pm 1.4$ \\
1000.0 & -0.00426 & 0.50308 & 1.0 & 3.041 & 0.968 & 6.542 & $661.8 \pm 2.6$ \\
1050.0 & -0.00495 & 0.13864 & 6.5 & 0.518 & 0.991 & 7.607 & $697.2 \pm 10.1$ \\
1100.0 & -0.01899 & 0.02962 & 29.0 & 0.121 & 0.994 & 29.176 & $1279.4 \pm 140.2$ \\
1150.0 & -0.02522 & 0.04422 & 19.5 & 0.476 & 1.000 & 38.739 & $1717.3 \pm 17.3$ \\
\hline
\end{tabular}

Note: Sample mass $=0.0986 \mathrm{gm}$. Average standard $J$-value $=0.009654 \pm 0.000215$. Integrated date $=613.1 \pm$ $13.6(\mathrm{Ma})$. Best estimate of age from ${ }^{36} \mathrm{Ar} /{ }^{40} \mathrm{Ar}$ vs. ${ }^{39} \mathrm{Ar} /{ }^{40} \mathrm{Ar}$ diagrams fitting points $3-11=626 \pm 45 \mathrm{Ma}$ $(Y$ intercept $=2778)$. Simple average of points $3-10=628+30,-28 \mathrm{Ma}(1 \sigma) . \mathrm{T}=$ temperature, Atmos. $=$ atmosphere, and Cum. = cumulative.

${ }^{a} f_{1}=1 /[1-(37 / 39) C a /(37 / 39) M]$, and $f_{2}=[1-(36 / 39) C a /(36 / 39) M]$, where $0 \mathrm{Ca}=$ isotope ratio of argon extracted from irradiated calcium salts and $0 \mathrm{M}=$ isotope ratio of argon extracted from irradiated unknown.

${ }^{\mathrm{b}} \mathrm{Cum} . \mathrm{f}(39)=$ cumulative fraction of ${ }^{39} \mathrm{Ar}$ released in each step.

${ }^{c}$ Date $(\mathrm{Ma})=$ ages were calculated by means of the following constants: lambda/epsilon $=0.581 \mathrm{E}-10 / \mathrm{yr}$; lambda/beta $=4.961 \mathrm{E}-10 / \mathrm{yr} .40 \mathrm{~K} / \mathrm{K}=0.01167$ atom $\%$. The quoted error is one standard deviation and does not include the error in the $J$-value or the standard error. Integrated date $=$ date and error calculated from the sum total from all steps; the error includes the error in the $J$-value.

Table 3. ${ }^{40} \mathrm{Ar} /{ }^{39} \mathrm{Ar}$ analytical data from Seychelles Site 5 whole-rock samples.

\begin{tabular}{rccccccc}
\hline $\begin{array}{c}\mathrm{T} \\
\left({ }^{\circ} \mathrm{C}\right)\end{array}$ & ${ }^{\mathrm{a}_{\mathrm{f}_{1}}}$ & ${ }^{\mathrm{a}_{\mathrm{f}}}$ & $\begin{array}{c}\text { Atmos. } \\
(\%)\end{array}$ & $\begin{array}{c}{ }^{40} \mathrm{Ar} \\
\left(\times 10^{-6} \mathrm{~cm}^{3} \mathrm{STP}\right)\end{array}$ & $\begin{array}{c}{ }^{\mathrm{b}} \mathrm{Cum} . \\
\mathrm{f}(39)\end{array}$ & ${ }^{37} \mathrm{Ar}_{\mathrm{Ca}}{ }^{39} \mathrm{Ar}_{\mathrm{K}}$ & $\begin{array}{c}{ }^{\mathrm{c}} \mathrm{Age} \\
(\mathrm{Ma})\end{array}$ \\
\hline 550.0 & -0.00041 & 0.02382 & 9.3 & 1.641 & 0.122 & 0.631 & $487.9 \pm 4.4$ \\
600.0 & -0.00022 & 0.06100 & 1.0 & 2.071 & 0.248 & 0.339 & $579.9 \pm 2.1$ \\
650.0 & -0.00038 & 0.08951 & 1.2 & 2.062 & 0.380 & 0.584 & $557.6 \pm 2.4$ \\
700.0 & -0.00068 & 0.17030 & 0.9 & 1.787 & 0.480 & 1.042 & $622.6 \pm 2.7$ \\
750.0 & -0.00097 & 0.43554 & 0.4 & 1.222 & 0.560 & 1.485 & $548.8 \pm 3.8$ \\
800.0 & -0.00166 & 0.20633 & 1.7 & 0.841 & 0.606 & 2.553 & $630.4 \pm 8.1$ \\
850.0 & -0.00263 & 0.28656 & 1.9 & 0.996 & 0.667 & 4.037 & $581.5 \pm 6.5$ \\
899.0 & -0.00377 & 0.39321 & 1.6 & 1.687 & 0.765 & 5.792 & $601.6 \pm 3.4$ \\
925.0 & -0.00396 & 0.29954 & 2.2 & 1.411 & 0.838 & 6.088 & $668.3 \pm 3.3$ \\
950.0 & -0.00369 & 0.42864 & 1.2 & 1.166 & 0.896 & 5.665 & $681.8 \pm 8.3$ \\
975.0 & -0.00314 & 0.19208 & 3.5 & 0.826 & 0.944 & 4.818 & $605.0 \pm 7.0$ \\
1000.0 & -0.00453 & 0.08507 & 11.3 & 0.456 & 0.970 & 6.965 & $614.5 \pm 8.5$ \\
1050.0 & -0.01355 & 0.10454 & 18.9 & 0.331 & 0.986 & 20.816 & $721.4 \pm 22.7$ \\
1100.0 & -0.03805 & 0.13725 & 19.6 & 0.523 & 1.000 & 58.449 & $1112.3 \pm 25.2$ \\
\hline
\end{tabular}

Note: Sample mass $=0.0995 \mathrm{gm}$. Average standard $J$-value $=0.009654 \pm 0.000215$. Integrated date $=598.4 \pm$ 13.6 (Ma). No meaningful linear trend in ${ }^{36} \mathrm{Ar} /{ }^{40} \mathrm{Ar}$ vs. ${ }^{39} \mathrm{Ar} /{ }^{40} \mathrm{Ar}$ plot. Simple average of points $2-11=611$ $+48,-42 \mathrm{Ma}(1 \sigma) . \mathrm{T}=$ temperature, Atmos. = atmosphere, and Cum. = cumulative.

${ }^{a} f_{1}=1 /[1-(37 / 39) \mathrm{Ca} /(37 / 39) \mathrm{M}]$, and $\mathrm{f}_{2}=[1-(36 / 39) \mathrm{Ca} /(35 / 39) \mathrm{M}]$, where $0 \mathrm{Ca}=$ isotope ratio of argon extracted from irradiated calcium salts and $0 \mathrm{M}=$ isotope ratio of argon extracted from irradiated unknown. ${ }^{b} \mathrm{Cum}$. $\mathrm{f}(39)=$ cumulative fraction of ${ }^{39} \mathrm{Ar}$ released in each step.

${ }^{c}$ Date $(\mathrm{Ma})=$ ages were calculated by means of the following constants: lambda/epsilon $=0.581 \mathrm{E}-10 / \mathrm{yr}$; lambda $/$ beta $=4.961 \mathrm{E}-10 / \mathrm{yr} .40 \mathrm{~K} / \mathrm{K}=0.01167$ atom $\%$. The quoted error is one standard deviation and does not include the error in the $J$-value or the standard error. Integrated date $=$ date and error calculated from the sum total from all steps; the error includes the error in the $J$-value.

\section{REFERENCES}

Baker, B. H., 1963. Geology and mineral resources of the Seychelles archipelago. Mem. Geol. Surv. Kenya, No. 3.

Baker, B. H., and Miller, J. A., 1963. Geology and geochronology of the Seychelles Islands and structures of the floor of the Arabian Sea. Nature, 199:346-348.

Emerick, C. M., 1985. Geochronology and geochemistry of lavas from the Comores Islands and northern Madagascar [Ph.D. dissert.]. Oregon State Univ., Corvallis.

Emerick, C. M., and Duncan, R. A., 1982. Age-progressive volcanism in the Comores Archipelago, western Indian Ocean and implications for Somali plate tectonics. Earth Planet. Sci. Lett., 60:415-428.

Kirschvink, J. L., 1980. The least-squares line and plane and the analysis of paleomagnetic data. Geophys. J. R. Astron. Soc., 62:699-710.
Kroner, A., McWilliams, M. O., Germs, G.J.B., Reid, A. B., and Schalk, K.E.L., 1980. Paleomagnetism of late Precambrian to early Paleozoic mixtite-bearing formations in Namibia (southwest Africa): the Nama Group and Blaubeker Formation. Am. J. Sci., 280:942-968.

Macintyre, R. M., Dickin, A. P., Fallick, A. E., Halliday, A. N., and Stephens, W. E., 1985. An isotopic and geochronologic study of the younger igneous rocks of the Seychelles. Eos, 66:1137.

Matthews, D. H., and Reilly, T. A., 1964. Disappointing interim paleomagnetic results from the Seychelles. Nature, 203:1160.

\section{Ms 115B-139}

Date of initial receipt: 1 March 1989

Date of acceptance: 13 November 1989 

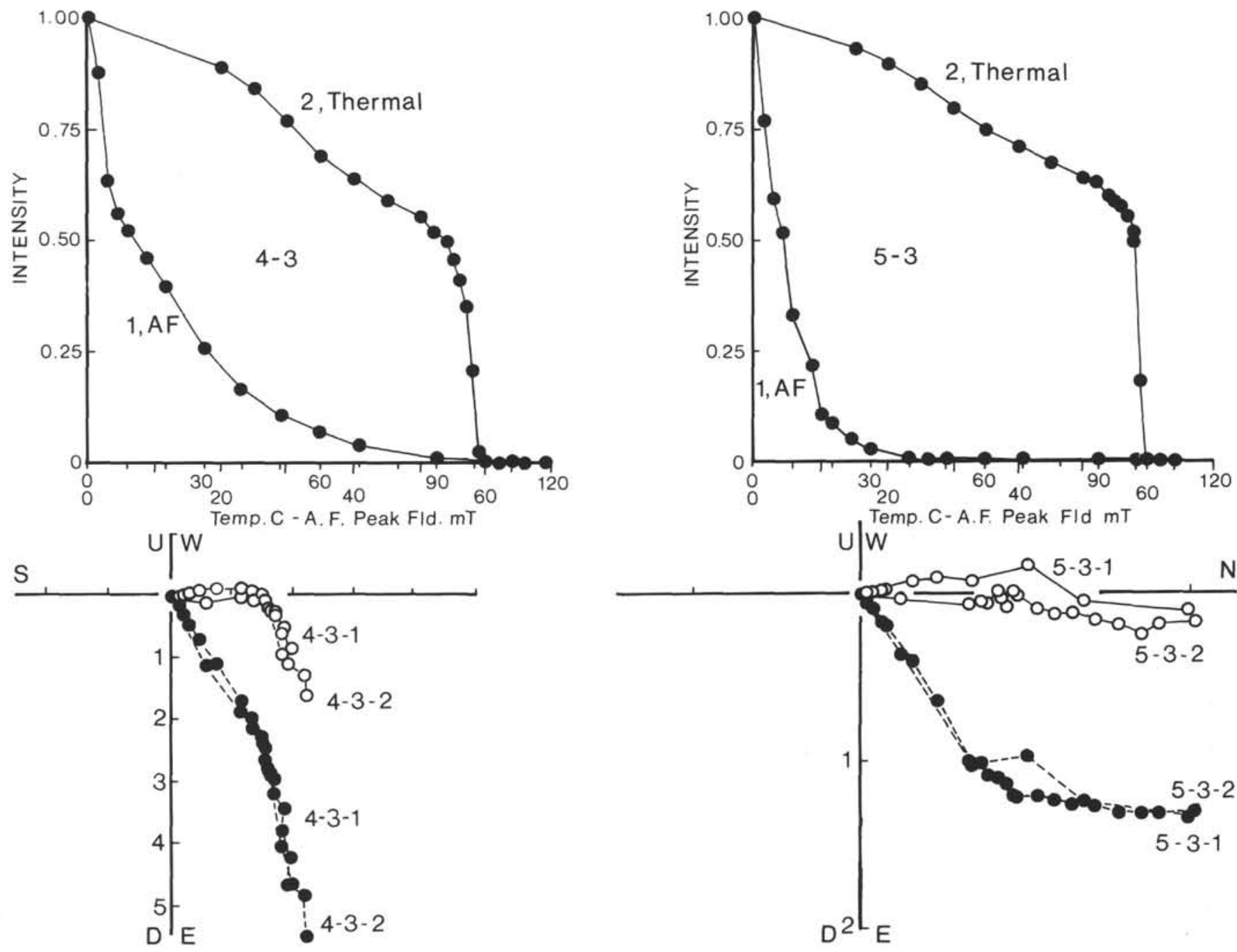

Figure 3. Normalized intensity plots of alternating-field (1) and thermal (2) demagnetization of specimens obtained from Sites 4 and 5 (Samples 4-3 and 5-3; top two plots). Orthogonal projections of alternating-field (closed circles) and thermal (open circles) demagnetization results (bottom two plots).

Table 4. Paleomagnetic field directions of late Precambrian dikes from the Seychelles Islands.

\begin{tabular}{ccccrr}
\hline Site & $N$ & D & I & $\kappa$ & $\alpha_{95}$ \\
\hline 4 & 6 & 343.1 & 51.4 & 263 & 4.1 \\
5 & 6 & 352.9 & 49.7 & 41 & 10.6 \\
Mean & 2 & 348.1 & 50.7 & 316 & 14.1 \\
\hline
\end{tabular}

Note: $N=$ number of samples, $\mathrm{D}=$ declination, $\mathrm{I}=$ inclination, $\kappa=$ Fisher's $\mathrm{K}$, and $\alpha_{95}=$ cone of confidence.

Table 5. Plate rotation poles for restoration of the Seychelles Islands to Africa, with successive paleomagnetic pole positions.

\begin{tabular}{lccccc}
\hline \multicolumn{1}{c}{ Rotation } & $\begin{array}{c}\text { Latitude } \\
\left({ }^{\circ} \mathrm{N}\right)\end{array}$ & $\begin{array}{c}\text { Longitude } \\
\left({ }^{\circ} \mathrm{E}\right)\end{array}$ & $\begin{array}{c}\text { Angle } \\
\left({ }^{\circ} \mathrm{CW}\right)\end{array}$ & $\begin{array}{c}\text { Pole position } \\
\text { (latitude/longitude) }\end{array}$ \\
\hline & & & & 52.3 & 38.6 \\
Seychelles-Madagascar & 18.7 & 25.8 & 15.5 & 47.5 & 50.3 \\
Madagascar-Africa & 1.9 & 105.6 & 16.9 & 60.2 & 65.4 \\
\hline
\end{tabular}

